\title{
A STUDY ON QUALITY OF WORK LIFE AMONG THE EMPLOYEES
}

\section{OF THE HEALTH CARE INDUSTRY}

\section{SUBRAHMANYA BHAT K. M}

Chartered Accountant, Research Scholar, Associate Professor and Former HOD, Department of Commerce and

Management, Shree Damodar College, Margao-Goa, India

\begin{abstract}
Every organisation has the onus to improve the quality of work life of its employees, as this is related to the productivity of the organisation. Better quality of work life improves the employee morale, commitment and interest towards their work. This congenial environment would motivate the employees for greater growth. This paper discusses the quality of work life of the workers of the health care industry, the factors contributing to quality of work life and the problems faced by them. The consequences and the remedies are presented through a systematic time bound study of selected multi speciality hospitals in Mangalore.

KEYWORDS: Quality of Work Life, Job Security, Perception \& Organizational Environment
\end{abstract}

Received: Sep 13, 2018; Accepted: Oct 04, 2018; Published: Oct 11, 2018; Paper Id.: IJHRMROCT20188

\section{INTRODUCTION}

The technological growth had made all the industries work round the clock and provide seamless service to the customers. As a result, the working environment has undergone considerable change and all the sectors now focus on enhanced customer satisfaction. The employees strive for organisational excellence, as it is the norm of the day. There is an unsaid rule to perform or perish. When speaking of the family system, nuclear families with both the parents working are the prevailing societal scenario. Maids and nannies are employed for all household and child care activities. Any slight change in the schedule would put the working parents in a precarious situation, as they seldom have other members at home to lend them a helping hand. This is bound to increase their stress and lead to conflicts. The increasing challenges, both at home and work had to be handled well by the present generation. The organisational environment plays a vital role in determining the quality of work life and the job satisfaction of the employee. If the work stress is carried over to the family, it leads to various imbalances and takes a toll on the individual's well being.

This study focuses on the quality of work life of the employees of the health care industry. The hospitals are important service providers and the health care needs of the society are increasing day by day. From paediatrics to geriatrics, health care services are always in demand, and India has gained a remarkable name for medical tourism. Mangalore has become one such prominent place for health care, where people from all over the nation and various foreign countries avail the services. The employees of multi speciality hospitals work under enormous pressure in a challenging environment, where they deal with myriad number of customers. It is imperative for the employees to have enough awareness about the quality of their work life and this study investigates those aspects. 


\section{NEED FOR STUDY}

The study attempts to know the perception of employee towards the quality of work life experienced by them in the hospital. The increasing demands from work and family results in increased stress and conflict within present workers (Edwards \& Rothbard, 2000). It is an effort to understand the influence of various factors that contributes to existence of QWL. Five multispecialty hospitals located in Mangalore were taken for this study.

\section{RESEARCH METHODOLOGY}

The study has adopted convenient sampling method, and the respondents are from five multi-specialty hospitals in Mangalore. The study was carried out for a period of four months. A structured questionnaire was framed to collect the primary data from the chosen sample. The reliability of the questionnaire was checked using Cronbach's Alpha method and the value obtained was 0.630 which denotes that, it is highly reliable. Appropriate statistical tools were used to analyze and extract results from the data gathered from the respondents. SPSS was employed to do the analysis.

\section{OBJECTIVES OF THE STUDY}

- To analyse the perception of employee's on quality of work life in multi speciality hospitals located at Mangalore.

- To understand the factors influencing the quality of work life in a multi speciality hospital.

- To study the impact of organisational environment on quality of work life.

- To suggest effective measures to improve the quality of work life based on the outcomes.

\section{REVIEW OF LITERATURE}

Various researchers have analyzed the concept of quality of work life for different industries. The recent researches on this topic have been included here to understand the existing gap in this area. K. R. Nia\& Maryam Maleki (2013) had studied the relationship between quality of work life and organizational commitment of faculty members at Islamic Azad University. The sample consisted 127 faculty members by employment of random stratified sampling. Spearman's correlation coefficient, multiple correlation method, LISREL and Friedman Test were used for data analysis. The T- statistic and Fisher statistic were applied to measure the demographic variables. The result showed that there was positive relationship between QWL and organizational commitment. This emphasizes that organization commitment prevails when QWL is good.

S. Khodadadi et al (2014) investigated the effect of QWL on the employees' job satisfaction in a private hospital. 114 employees were selected in random for this study, and two questionnaires on "quality of work life" and "job satisfaction" were administered. SPSS and LISREL software were used for data analysis. The results of the study revealed that the salary and benefit policies of the organization have a significant and positive effect on job satisfaction.

Indumathy. R, Kamalraj. S (2012) in her research has enumerated the major factors that influence and decide the Quality of Work Life. Attitude, environment, opportunities, nature of job, people, stress level, career prospects, challenges, growth and development and risk involved in the work and rewards were found to be the major factors.

Barbara Buddeberg and Fisher (2008) in their article suggest that, a well-balanced integration of professional and private life is an essential goal for the new generation of doctors. This applies even more to female doctors and family 
physicians.

Bhargava and Baral (2009) in their study had examined the antecedents and outcomes of work family enrichment. The sample comprised of 245 employees from manufacturing and information technology sector in India. Core self evaluations, family support and supervisor support were positively related to family-to-work enrichment, whereas job whereas job characteristics namely, autonomy, skill set, task identity, task significance were positively related to workto-family enrichment. This results in job satisfaction, affective commitment and organizational citizenship behaviour.

Millicent F. Nelson and Richard J. Tarpey (2010) had examined that, one of the areas of satisfaction for nurses is the availability of work force schedules. The results of this study indicate perceptions of fairness for the actual work schedules (distributive justice) as well as the process used to generate that schedule (procedural justice) are important for satisfaction with the assigned schedule. This satisfaction arises out of the additional options provided for nurses, and it is a better means to attract and retain them.

Wane et al (2012) in their article titled "Measuring the Quality of Nursing Work life in public Hospitals" examined the underlying factors that measures QWL of nurses in state level public hospitals in Malaysia. The study revealed that there is a high nursing staff turnover within the sector due to lack of Quality of work life. The hospital management could enhance the QWL by providing opportunities for career growth and "Work-family life balance". They also concluded that nurses should be treated as "assets" instead of perceiving them as "cost" and making them to participate in managing and decisions making process.

SanthanaLakshmi and Ramachandran (2012) in their article, 'Analysis of work life balance of female nurses in hospitals' had identified the issues connected with work life balance of Staff Nurses in Government hospitals and private hospitals in Tamilnadu India. The results indicated that both government and private hospital nurses work life balance is a challengeable one. It is also revealed that as compared to government hospitals the private hospital management needs to be conscious of the status of nurses and periodically review their work and personal life satisfaction.

R. Manju Shree (2012) in her article titled "Work Life Balance \& Marital Satisfaction of Critical Care Nurses in Private Hospitals at Coimbatore" studied about the nursing personnel's physical, psychological and medical effects of night work and if night shifts extended working hours are regularly performed, it results in spouse conflict which, in turn, is associated with less marital satisfaction. It is also important to understand the effects of increased work hours on marriage, as it may have a detrimental effect on relationships in the long run.

Ipseeta satpathy and B. Chandra Mohan patnaik (2014) in their article titled "A comparative study on Work- life Balance of Nursing Staff working in Private and Government Hospitals" made a comparative study on Work-life balance of employees in government and private sectors from 337 respondents in total. The study reveals the general perception and impact of work-life balance towards the personal and professional life and influence of demographic factors on WLB.

The reviews of literature show that numerous studies had been conducted for analyzing the factors influencing the work life balance. There are also studies, which had apparently focused on work life balance of the employees in hospital industry. There are very few studies which have adopted a comprehensive approach in investigating the quality of work life of the employees of multi specialty hospitals in Mangalore. Hence, the present study has been undertaken to cover the above research gap. 


\section{DATA ANALYSIS AND INTERPRETATION}

Table 1: Summary of the Personal Attributes of the Respondents

\begin{tabular}{|c|c|c|}
\hline Particulars & Frequency & Percentage \\
\hline \multicolumn{3}{|c|}{ Gender } \\
\hline Female & 174 & 69.60 \\
\hline Male & 76 & 30.40 \\
\hline \multicolumn{3}{|c|}{ Age } \\
\hline 20-30 Yrs & 70 & 28.00 \\
\hline $30-40$ Yrs & 80 & 32.00 \\
\hline $40-50 \mathrm{Yrs}$ & 75 & 30.00 \\
\hline $50-60 \mathrm{Yrs}$ & 25 & 10.00 \\
\hline \multicolumn{3}{|c|}{ Occupation } \\
\hline Doctor & 35 & 14.00 \\
\hline Nurse & 120 & 48.00 \\
\hline Paramedical & 45 & 18.00 \\
\hline Administration & 50 & 20.00 \\
\hline \multicolumn{3}{|c|}{ Experience } \\
\hline$<1$ year & 30 & 12.00 \\
\hline 1-3 year & 80 & 32.00 \\
\hline 3-5 year & 82 & 32.80 \\
\hline$>5$ year & 58 & 23.20 \\
\hline
\end{tabular}

Source: Primary data

Table 2: Respondent's Opinion Regarding the Work Environment

\begin{tabular}{|c|c|c|c|c|c|c|c|c|c|c|c|}
\hline \multirow{2}{*}{ S. No } & \multirow{2}{*}{ Work Environment } & \multicolumn{2}{|c|}{ SDA } & \multicolumn{2}{|c|}{ DA } & \multicolumn{2}{|c|}{$\mathbf{N}$} & \multicolumn{2}{|c|}{$\mathbf{A}$} & \multicolumn{2}{|c|}{ SA } \\
\hline & & $\mathbf{F}$ & $\%$ & $\mathbf{F}$ & $\%$ & $\mathbf{F}$ & $\%$ & $\mathbf{F}$ & $\%$ & $\mathbf{F}$ & $\%$ \\
\hline 1 & Amicable Environment to work & 0 & 0 & 10 & 4 & 0 & 0 & 194 & 77.6 & 46 & 18.4 \\
\hline 2 & Work load not too heavy & 5 & 2 & 67 & 26.8 & 20 & 5.6 & 121 & 48.5 & 43 & 17.2 \\
\hline 3 & Clarity in work and organisational goals & 7 & 2.8 & 10 & 3.9 & 20 & 7.8 & 179 & 71.6 & 34 & 13.7 \\
\hline 4 & Participative in the organisation & 2 & .7 & 6 & 2.4 & 5 & 2.0 & 198 & 78.9 & 39 & 15.7 \\
\hline 5 & Flexible working Hours & 16 & 6.4 & 46 & 18.1 & 19 & 7.8 & 152 & 60.8 & 17 & 6.9 \\
\hline
\end{tabular}

Source: Primary data

The table depicts that 77.60 percent of the respondents agreed that, they are provided with good work environment. 48.50 percent of the respondents agreed with the statement that the work load is not too heavy. It was also observed that 71.60 percent agreed that there exists clarity in work and organizational goals.78.90 percent of the respondents agreed that they were empowered to participate in the organization. 60.80percent of them agreed that they enjoyed flexible working hours. 


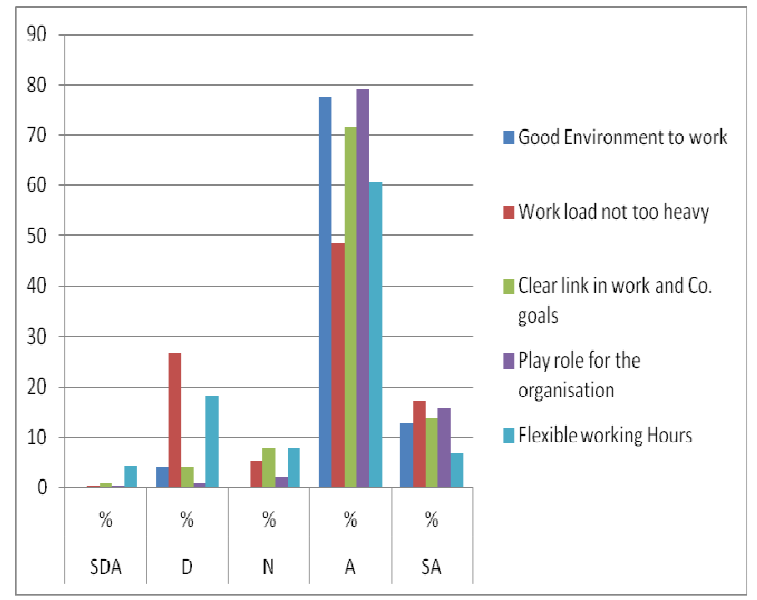

Source: Primary Data

Figure 1: Respondents' Opinion Regarding the Work Environment

$\mathrm{H} 0=$ There is no significant difference among gender and their opinion towards work environment.

$\mathrm{H} 1=$ There is significant difference among gender and their opinion towards work environment.

Table 3: Gender Vs Work Environment

\begin{tabular}{|c|c|c|c|c|c|c|}
\hline Work Environment & & Sum of Squares & Df & Mean Square & $\mathbf{F}$ & Sig. \\
\hline \multirow{3}{*}{ Good environment to work } & Between Groups & 14.915 & 1 & 14.915 & \multirow{3}{*}{57.829} & \multirow{3}{*}{.004} \\
\hline & Within Groups & 51.065 & 198 & .258 & & \\
\hline & Total & 65.980 & 199 & & & \\
\hline \multirow{3}{*}{ Work load is not too heavy \& tiring } & Between Groups & 90.242 & 1 & 90.242 & \multirow{3}{*}{125.026} & \multirow{3}{*}{.032} \\
\hline & Within Groups & 142.913 & 198 & .722 & & \\
\hline & Total & 233.155 & 199 & & & \\
\hline \multirow{3}{*}{ Link between work and goal of organization } & Between Groups & 22.485 & 1 & 22.485 & \multirow{3}{*}{62.690} & \multirow{3}{*}{.007} \\
\hline & Within Groups & 71.015 & 198 & .359 & & \\
\hline & Total & 93.500 & 199 & & & \\
\hline \multirow{3}{*}{ Play my role for organization's success } & Between Groups & 14.932 & 1 & 14.932 & \multirow{3}{*}{82.441} & \multirow{3}{*}{.021} \\
\hline & Within Groups & 35.863 & 198 & .181 & & \\
\hline & Total & 50.795 & 199 & & & \\
\hline \multirow{3}{*}{ Flexible working hours } & Between Groups & 49.986 & 1 & 49.986 & \multirow{3}{*}{63.456} & \multirow{3}{*}{.009} \\
\hline & Within Groups & 155.969 & 198 & .788 & & \\
\hline & Total & 205.955 & 199 & & & \\
\hline
\end{tabular}

Source: Primary data

The F-value is greater than the table value; hence the hypothesis $\left(\mathrm{H}_{1}\right)$ is accepted and null hypothesis is rejected. There is a significant difference among gender and their opinion towards their work environment.

$\mathrm{H} 0=$ There is no significant difference among gender and their opinion towards organization culture and climate

$\mathrm{H} 1=$ There is significant difference among gender and their opinion towards organization culture and climate 
Table 4: Gender Vs Organization Culture and Climate

\begin{tabular}{|c|c|c|c|c|c|c|}
\hline \multicolumn{7}{|c|}{ Anova } \\
\hline Organisation Culture \& Climate & & $\begin{array}{l}\text { Sum of } \\
\text { Squares }\end{array}$ & Df & $\begin{array}{l}\text { Mean } \\
\text { Square }\end{array}$ & $\mathbf{F}$ & Sig. \\
\hline \multirow{3}{*}{$\begin{array}{l}\text { The climate culture of the organization } \\
\text { of the organization is good }\end{array}$} & $\begin{array}{l}\text { Between } \\
\text { Groups }\end{array}$ & 11.007 & 1 & 11.007 & \multirow{3}{*}{60.968} & \multirow{3}{*}{.004} \\
\hline & $\begin{array}{l}\text { Within } \\
\text { Groups }\end{array}$ & 35.748 & 198 & .181 & & \\
\hline & Total & 46.755 & 199 & & & \\
\hline \multirow{3}{*}{ Opportunity to learn new things on the job } & $\begin{array}{l}\text { Between } \\
\text { Groups }\end{array}$ & 55.955 & 1 & 55.955 & \multirow{3}{*}{219.976} & \multirow{3}{*}{.021} \\
\hline & $\begin{array}{l}\text { Within } \\
\text { Groups }\end{array}$ & 50.365 & 198 & .254 & & \\
\hline & Total & 106.320 & 199 & & & \\
\hline \multirow{3}{*}{$\begin{array}{l}\text { Employees have rights to be heard of their } \\
\text { suggestions or complaints }\end{array}$} & $\begin{array}{l}\text { Between } \\
\text { Groups }\end{array}$ & 20.419 & 1 & 20.419 & \multirow{3}{*}{57.287} & \multirow{3}{*}{.011} \\
\hline & $\begin{array}{l}\text { Within } \\
\text { Groups }\end{array}$ & 70.576 & 198 & .356 & & \\
\hline & Total & 90.995 & 199 & & & \\
\hline \multirow{3}{*}{$\begin{array}{l}\text { As part of Culture \& commitment building, } \\
\text { the organization conducts sports \& cultural } \\
\text { activities for the employees. }\end{array}$} & $\begin{array}{l}\text { Between } \\
\text { Groups }\end{array}$ & 37.308 & 1 & 37.308 & \multirow{3}{*}{191.534} & \multirow{3}{*}{.009} \\
\hline & $\begin{array}{l}\text { Within } \\
\text { Groups }\end{array}$ & 38.567 & 198 & .195 & & \\
\hline & Total & 75.875 & 199 & & & \\
\hline \multirow{3}{*}{$\begin{array}{l}\text { General climate here is congenial \& people } \\
\text { would like to work in this organization. }\end{array}$} & $\begin{array}{l}\text { Between } \\
\text { Groups }\end{array}$ & 17.201 & 1 & 17.201 & \multirow{3}{*}{33.668} & \multirow{3}{*}{.020} \\
\hline & $\begin{array}{l}\text { Within } \\
\text { Groups }\end{array}$ & 101.154 & 198 & .511 & & \\
\hline & Total & 118.355 & 199 & & & \\
\hline \multirow{3}{*}{$\begin{array}{l}\text { There is no caste, racial, sex discrimination } \\
\text { made by the employees in the organization. }\end{array}$} & $\begin{array}{l}\text { Between } \\
\text { Groups }\end{array}$ & 45.568 & 1 & 45.568 & \multirow{3}{*}{339.352} & \multirow{3}{*}{.010} \\
\hline & $\begin{array}{l}\text { Within } \\
\text { Groups }\end{array}$ & 26.587 & 198 & .134 & & \\
\hline & Total & 72.155 & 199 & & & \\
\hline \multirow{3}{*}{$\begin{array}{l}\text { Feel secure in the job and would recommend } \\
\text { this organization as good place to work. }\end{array}$} & $\begin{array}{l}\text { Between } \\
\text { Groups }\end{array}$ & 21.932 & 1 & 21.932 & \multirow{3}{*}{58.476} & \multirow{3}{*}{.008} \\
\hline & $\begin{array}{l}\text { Within } \\
\text { Groups }\end{array}$ & 74.263 & 198 & .375 & & \\
\hline & Total & 96.195 & 199 & & & \\
\hline \multirow{3}{*}{$\begin{array}{l}\text { People feel free to express their opinions and } \\
\text { ideas differing from their seniors. }\end{array}$} & $\begin{array}{l}\text { Between } \\
\text { Groups }\end{array}$ & 34.303 & 1 & 34.303 & \multirow{3}{*}{58.767} & \multirow{3}{*}{.023} \\
\hline & $\begin{array}{l}\text { Within } \\
\text { Groups }\end{array}$ & 115.572 & 198 & .584 & & \\
\hline & Total & 149.875 & 199 & & & \\
\hline
\end{tabular}

Source: Primary data

The F-value is greater than the table value; hence the hypothesis $\left(\mathrm{H}_{1}\right)$ is accepted and null hypothesis is rejected. There is a significant difference among gender and their opinion towards their Organization culture and climate. 


\section{FINDINGS}

- 69.60 percent of the employees are female while 30.40 percent are male.

- 14 percent of the employees are doctors, 18percent are paramedical staff, 20 percent are administrative staff and 48 percent are nurses. The majority of the respondents here are hence nurses whose service is essential round the clock.

- 23.20 percent employees have more than 5 years of experience, 32.80 percent have 3-5 years experience, 32 percent have 1-3 years and 12 percent have less than one year of experience.

- $\quad 77.50$ percent of the employees agreed that the working environment was good.

- 68.10 percent of the employees have responded that the organization provides sufficient job security to employees.

- 63 percent of the employees were happy with pay structure of the organization.

- 63 percent of the respondents were happy with the 360 degree performance appraisal system of the organization.

- It was found that 67 percent of the employees were satisfactory with the training programme from the organization and upgrading their knowledge.

- 70 percent of the respondents responded that the grievance system in the organization was effective.

- 33.50 percent of the respondents have opined that they don't have any leisure time in their work

- 72 percent of employees in organization felt that they were overall happy with their work environment.

\section{SUGGESTIONS}

The respondents have adequate awareness about the quality of work life and the working conditions seem fairly good. In spite of theses, there are areas which need improvement. The hospitals should focus on effective orientation for the employees. This could include a week long orientation, so that the employees are very clear about the working environment, the organization goals and their roles. Clear, written policy on job description should be provided to the employees. This would avoid conflicts at work place thus saving time and efficiency.

The employees should be provided on the job and off the job training on the latest techniques as health care is a fast growing sector with new developments. The employees should be trained on these aspects, so that they are able to achieve the key deliverables.

Adequate manpower strength is essential at all levels. When the existing staff is overloaded, it leads to stress, frustration and loss of interest in their current roles.

\section{CONCLUSIONS}

The study has emphasized the importance of quality of work life for the employees of the health care industry. The employees of this industry member are always engaged in patient care and work in critical situations, thereby confronting great challenges. The hospital management should ensure fair working environment, shifts and counseling to its employees. Proper work life balance of the staff members will tend to produce the conducive work environment. 
Sufficient care shall be taken to ensure adequate staff strength in all levels such as doctors, nurses, paramedical and administrative lines. The HR policies may be framed suitably in the aspect of number of working days, work load allocation, performance based promotions, and incentives. These measures would ensure better quality of work life, happy employees and in turn quality service to the public.

\section{REFERENCES}

1. K. R. Nia\& Maryam Maleki (2013), A study on the relationship between quality of work life and organizational commitment of faculty members at Islamic Azad University, International Journal of Research in Organizational Behavior and Human Resource Management, Vol. 1, No. 4

2. Indumathy. R. \& Kamalraj. S (2012), "A STUDY ON QUALITY OF WORK LIFE AMONG WORKERS WITH SPECIAL REFERENCE TO TEXTILE INDUSTRY IN TIRUPUR DISTRICT - A TEXTILE HUB”, International Journal of Multidisciplinary Research Vol.2 Issue 4, April 2012, ISSN 2231 -5780.

3. S. Khodadadi et al (2014) investigating the QWL dimensions effect on the employees' job satisfaction, Applied mathematics in Engineering, Management and Technology, 2(1)

4. Baral R.\& Bhargava S. (2010), Work-family enrichment as a mediator between organizational interventions for work-life balance and job outcomes. Journal of Managerial Psychology, 25,274-300.

5. Nelson, Millicent F \& Tarpey, Richard J., WORK SCHEDULING SATISFACTION AND WORK LIFE BALANCE FOR NURSES: THE PERCEPTION OF ORGANIZATIONAL JUSTICE, Source: Academy of Health Care Management Journal. 2010, Vol. 6 Issue 1, p25-36. 12p. 1

6. Naidu, J. (2016). Curbing staff turnover through employee engagement in the retail sector of Nagpur.

7. Ipseeta Satpathy \& Ms. Sasmita Jena (2014), A Comparative study on Work- Life Balance of Nursing Staff working in Private and Government Hospitals, International Journal of Innovative Research in Science, Engineering and Technology, Vol.3, Issue 1.

8. Manju Shree R, WORKLIFE BALANCE \& MARITAL SATISFACTION OF CRITICAL CARE NURSES IN PRIVATE HOSPITALS AT COIMBATORE, International journal of Management and Social science research, Vol.1, No.12, 2012

9. K. Santhana Lakshmi et al, Analysis of Work Life Balance of Female Nurses in Hospitals - Comparative Study between Government and Private Hospital in Chennai, TN., India, International Journal of Trade, Economics and Finance, Vol. 3, No. 3, June 2012 